\title{
Pelatihan Instalasi Penerangan Untuk Mahasiswa Teknik Elektro
}

\author{
Novi Kurniasih ${ }^{1}$; Dewi Purnama Sari ${ }^{2}$; Agung Untoro ${ }^{3}$; Santoso Janu Warsono ${ }^{4}$; \\ Irvan Buchari Tamam ${ }^{5}$; Wahyudi Sarimun ${ }^{6}$ \\ 1, 2, 3, 4, 5, 6 Program Studi Teknik Elektro, Institut Teknologi PLN \\ ${ }^{1}$ novi@itpln.ac.id
}

\begin{abstract}
The training of lighting installations for electrical engineering students is intended to provide an understanding of the electricity dangers and skills in terms of installing lighting installations that comply with PUIL standards. With the training of this lighting installation, it can help electrical engineering students to install and repair electrical installations independently even with having these skills can make those students open business opportunities so that employment opportunities will be open and at least they will have income for themselves. This training is given in two stages, namely the stage of supply material and the material testing phase, both theoretically and practically. With this training, the trainees are expected to understand well about the electricity dangers and how to secure it, read installation drawings, measure voltage, detect broken connections, and can make lighting installations using various switches and sockets that comply with the standards and conditions in PUIL and SPLN. In designing and installing electrical installations systems must be considered about human safety, other living things and the security of property from harm and damage that can be caused by the use of electrical installations. Through the Community Partnership Program, electrical engineering lecturer team of IT-PLN felt to need to conduct community training which is currently only focused on electrical engineering students of Pertamina University, by providing knowledge about lighting installation engineering skills. By utilizing experts in the electrical engineering department of IT-PLN, it is expected to be able to add skills and knowledge to electrical engineering students of Pertamina University. The trainees are expected to have an understanding of the electricity theory, the dangers of electricity and how to deal with it and have a strong desire to obtain theoretical and practical knowledge about electrical lighting installation techniques.
\end{abstract}

Keywords: Training, Lighting Installation, PUIL, SPLN

\begin{abstract}
ABSTRAK
Pelatihan instalasi penerangan untuk mahasiswa Teknik Elektro dimaksudkan untuk memberikan pemahaman tentang bahaya listrik dan keterampilan dalam perihal pemasangan instalasi penerangan yang sesuai dengan standar PUIL. Dengan adanya pelatihan instalasi penerangan ini dapat membantu mahasiswa Teknik Elektro melakukan pemasangan maupun perbaikan instalasi listrik secara mandiri bahkan dengan memiliki keterampilan tersebut dapat membuat mahasiswa Teknik Elektro membuka peluang usaha sehingga akan terbuka peluang kerja dan minimal akan mempunyai penghasilan untuk dirinya sendiri. Pelatihan ini diberikan dalam dua tahap, yaitu tahap pembekalan materi dan tahap pengujian materi, baik secara teori maupun praktek. Dengan pelatihan ini diharapkan peserta memahami dengan baik tentang bahaya listrik dan cara mengamankannya, membaca gambar instalasi, mengukur tegangan, mendeteksi sambungan yang putus, dan dapat membuat instalasi penerangan menggunakan berbagai macam sakelar dan stop kontak yang sesuai dengan standar dan ketentuan yang ada pada PUIL dan SPLN. Dalam mendesain dan melakukan pemasangan sistem instalasi listrik harus diperhatikan tentang keselamatan manusia, makhluk hidup lain dan keamanan harta benda dari bahaya dan kerusakan yang bisa ditimbulkan oleh penggunaan instalasi listrik. Tim dosen Teknik Elektro IT-PLN melalui Program Kemitraan Masyarakat merasa perlu mengadakan pelatihan terhadap masyarakat yang saat ini hanya difokuskan terlebih dahulu pada mahasiswa Teknik Elektro Universitas Pertamina, dengan memberikan pengetahuan tentang keterampilan teknik pemasangan instalasi penerangan.
\end{abstract}


Dengan memanfaatkan tenaga pakar yang ada di lingkungan prodi Teknik Elektro IT-PLN, diharapkan dapat menambah keterampilan dan pengetahuan bagi mahasiswa Teknik Elektro Universitas Pertamina. Peserta pelatihan nantinya diharapkan mempunyai pemahaman tentang teori kelistrikan, bahaya listrik dan cara menanggulanginya serta punya keinginan yang kuat untuk memperoleh ilmu secara teori dan praktek tentang teknik instalasi listrik penerangan.

Kata kunci: Pelatihan, Instalasi Penerangan, PUIL, SPLN 


\section{PENDAHULUAN}

\subsection{Analisis Situasi}

Permasalahan yang sering timbul dalam perihal instalasi listrik yaitu berupa korsleting arus listrik atau biasanya lebih dikenal dengan istilah hubung singkat yang sering disebabkan karena beberapa faktor antara lain yaitu:

- Terkelupasnya kabel listrik akibat faktor lingkungan

- Sambungan kabel dan penggunaan kabel yang tidak sesuai dengan standar keamanan

- Penumpukan beban secara berlebihan pada saluran listrik dikarenakan keawaman masyarakat yang tidak mengetahui standar keamanan instalasi listrik.

Akibat faktor-faktor tersebut, dapat menimbulkan bahaya listrik seperti kejut listrik dan panas sehingga menyebabkan kebakaran.

Dalam mendesain dan melakukan pemasangan sistem instalasi listrik harus diperhatikan tentang keselamatan manusia, makhluk hidup lain dan keamanan harta benda dari bahaya dan kerusakan yang bisa ditimbulkan oleh penggunaan instalasi listrik. Ada lima prinsip dasar yang harus diperhatikan dalam melakukan pemasangan instalasi listrik yaitu:

- Keamanan

- Keandalan

- Kemudahan tercapai

- Ketersediaan dan

- Ekonomis.

Prinsip dasar instalasi listrik yang paling utama adalah keamanan (safety) yang ditujukan untuk manusia, harta milik maupun binatang. Keamanan bagi manusia berarti instalasi listrik harus aman bagi orang yang memasang, mengoperasikan dan yang merawat atau memperbaikinya karena arus listrik sangat berbahaya. Sebagai sumber energi, listrik harus digunakan tanpa banyak menimbulkan bahaya.

Untuk mengurangi bahaya akibat penggunaan dan pemasangan instalasi listrik yang tidak sesuai dengan standar keamanan, maka dibuatlah suatu standar keamanan listrik di Indonesia yang lebih dikenal dengan istilah PUIL (Persyaratan Umum Instalasi Listrik). Oleh karena itu pemasangan instalasi listrik harus sesuai dengan prosedur dan standar yang telah ditetapkan PUIL. Selain itu, instalasi listrik harus berfungsi dalam keadaan baik dan sesuai dengan maksud penggunaannya. Agar tingkat keawaman masyarakat mengenai pemasangan instalasi listrik yang baik dan benar dapat didegradasi, maka dilakukanlah suatu kegiatan Program Kemitraan Masyarakat yang mengangkat topik tentang pelatihan instalasi penerangan. Adapun khalayak yang menjadi sasaran untuk melaksanakan pelatihan instalasi penerangan ini, dimana untuk saat ini hanya difokuskan untuk kalangan mahasiswa Teknik Elektro.

\subsection{Permasalahan Mitra}

Pemahaman masyarakat tentang bahaya listrik dan pengetahuan instalasi listrik yang aman dan sesuai standar masih sangat kurang. Oleh karena itu perlu adanya suatu kegiatan Program Kemitraan Masyarakat dari pihak universitas atau sekolah tinggi terutama yang memiliki prodi teknik elektro dengan konsentrasi bidang teknik tenaga listrik berupa pelatihan di bidang ketenagalistrikan baik cara pembangunan, pemasangan, dan pemeliharaannya. Keberadaan dunia pendidikan tinggi khusususnya pendidikan teknik tenaga listrik menjadikan masyarakat paham dan mengerti tentang cara pemasangan dan pemeliharaan instalasi listrik khususnya instalasi listrik untuk rumah tinggal setelah mengikuti pelatihan. 
Pemasangan instalasi listrik tentunya harus mengacu pada PUIL, sehingga terjamin kualitasnya baik secara teknis, ekonomis dan dijamin keandalannya. Tetapi kenyataan di lapangan banyak ditemui instalasi listrik yang tidak sesuai standar dan pemasangan instalasi listrik yang sembarangan seperti penumpukan beban yang berlebihan, ukuran kabel dan teknik sambungan kabel yang tidak sesuai standar. Padahal listrik sangat besar bahayanya jika pemasangannya secara tidak benar dan tidak sesuai dengan PUIL dan SPLN yang berlaku. Berdasarkan permasalahan di atas maka tim dosen Teknik Elektro IT-PLN melalui Program Kemitraan Masyarakat merasa perlu mengadakan pelatihan terhadap masyarakat yang saat ini hanya difokuskan terlebih dahulu pada mahasiswa Teknik Elektro, dengan memberikan pengetahuan tentang keterampilan teknik pemasangan instalasi penerangan. Dengan memanfaatkan tenaga pakar yang ada di lingkungan program studi Teknik Elektro IT-PLN, diharapkan dapat menambah keterampilan dan pengetahuan bagi mahasiswa Teknik Elektro yang bersedia diberikan keterampilan. Peserta pelatihan nantinya diharapkan pemahamannya tentang teori kelistrikan, bahaya listrik dan cara menanggulanginya serta punya keinginan yang kuat untuk memperoleh ilmu secara teori dan praktek tentang teknik instalasi listrik penerangan.

\subsection{Solusi yang Ditawarkan}

Adapun solusi yang ditawarkan dalam kegiatan PKM ini adalah:

1. Mengedukasi peserta pelatihan mengenai bahaya listrik dan bagaimana penggunaan listrik yang aman

2. Menambah wawasan ilmu pengetahuan dan pemahaman peserta tentang teori kelistrikan terutama teknik pemasangan instalasi listrik penerangan yang baik dan benar untuk bangunan, yang sesuai dengan standar PUIL dan SPLN, dengan cara memberikan penjelasan materi dan praktek pemasangan instalasi oleh masing-masing peserta yang diawasi langsung oleh instruktur pelatihan.

\section{METODE}

Adapun metode pelaksanaaan kegiatan PKM ini dapat dideskripsikan dalam beberapa tahapan yang dapat dilihat pada tabel berikut ini.PKM

Tabel 1. Tahapan Deskripsi Kegiatan PKM

\begin{tabular}{|c|l|c|}
\hline NO & \multicolumn{1}{|c|}{ KEGIATAN } & TANGGAL \\
\hline 1 & Survei pertama kebutuhan mitra & 5 September 2018 \\
\hline 2 & $\begin{array}{l}\text { Melakukan diskusi dengan tim pelaksana kegiatan PKM untuk } \\
\text { menganalisis kebutuhan/permasalahan yang dihadapi mitra }\end{array}$ & 6 September 2018 \\
\hline 3 & $\begin{array}{l}\text { Merancang format pelaksanaan kegiatan PKM sesuai kebutuhan } \\
\text { mitra }\end{array}$ & 8 September 2018 \\
\hline 4 & $\begin{array}{l}\text { Survei kedua menawarkan kepada mitra format/luaran kegiatan } \\
\text { PKM yang sudah dirancang oleh tim pelaksana kegiatan PKM } \\
\text { sebagai solusi dari permasalahan yang dihadapi mitra }\end{array}$ & 12 September 2018 \\
\hline 5 & $\begin{array}{l}\text { Merancang bentuk luaran sebagai format pelaksanaan kegiatan } \\
\text { PKM dengan materi sebagai berikut: }\end{array}$ & $\begin{array}{l}\text { 13 September } 2018 \\
14 \text { September 2018 } \\
\text { Memberikan penjelasan mengenai tata cara pemasangan } \\
\text { instalasi listrik penerangan yang baik dan benar beserta } \\
\text { komponen-komponennya, kepada mahasiswa/mahasiswi } \\
\text { Teknik Elektro Universitas Pertamina }\end{array}$ \\
\hline
\end{tabular}


Terang: Jurnal Pengabdian Pada Masyarakat Menerangi Negeri

e-ISSN: 2655-5948

Vol. 2, No. 2, Juli 2020

P-ISSN: 2655-5956

DOI: https://doi.org/10.33322/terang.v2i2.429

Hal. $126-136$

\begin{tabular}{|c|c|c|}
\hline & 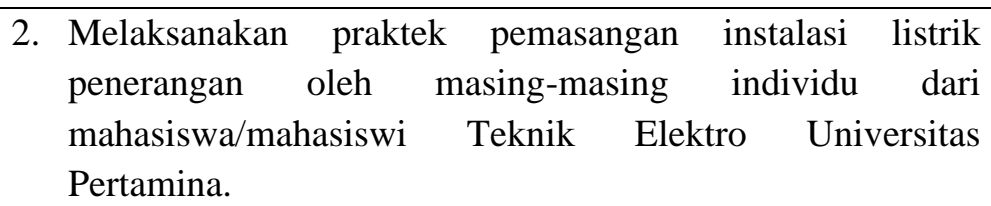 & \\
\hline 6 & $\begin{array}{l}\text { Mengusulkan proposal kegiatan PKM kepada pihak kampus } \\
\text { atas hasil diskusi dengan pihak mitra }\end{array}$ & 21 September 2018 \\
\hline 7 & $\begin{array}{l}\text { Proposal tim pelaksana kegiatan PKM disetujui oleh pihak } \\
\text { kampus }\end{array}$ & 16 Oktober 2018 \\
\hline 8 & $\begin{array}{l}\text { Melakukan rapat koordinasi tim pelaksana kegiatan PKM untuk } \\
\text { persiapan pelaksanaan kegiatan PKM }\end{array}$ & $\begin{array}{l}\text { 9-10 November } 2018 \\
\text { 3-4 Januari } 2019\end{array}$ \\
\hline 9 & Membuat kesepakatan dengan mitra untuk waktu pelaksanaan & 15 Januari 2019 \\
\hline 10 & Pelaksanaan kegiatan PKM & 24-26 Januari 2019 \\
\hline 11 & Mengevaluasi hasil kegiatan PKM yang dilaksanakan & 30-31 Januari 2019 \\
\hline 12 & $\begin{array}{l}\text { Menerima surat keterangan telah melakukan kegiatan PKM dari } \\
\text { Ketua Program Studi Teknik Elektro Universitas Pertamina } \\
\text { (Mitra) }\end{array}$ & 4 Februari 2019 \\
\hline 13 & $\begin{array}{l}\text { Membuat laporan pertanggungjawaban pelaksanaan kegiatan } \\
\text { PKM }\end{array}$ & 6-20 Februari 2019 \\
\hline
\end{tabular}

\section{HASIL DAN PEMBAHASAN}

Kegiatan PKM yang mengangkat topik tentang pelatihan instalasi listrik penerangan ini dilaksanakan di Universitas Pertamina, lebih tepatnya bertempat di Laboratorium Instrumentasi dan Pengukuran Listrik, dengan alamat jalan Teuku Nyak Arief, kawasan Simprug, Kebayoran Lama, Jakarta Selatan. Pelaksanaaan kegiatan PKM tersebut diselenggarakan pada tanggal 24-26 Januari 2019 dan berlangsung dari pukul 09.00 WIB sampai dengan selesai.

Pelatihan instalasi listrik penerangan ini diikuti oleh mahasiswa/mahasiswi Teknik Elektro Universitas Pertamina dari berbagai angkatan. Adapun metode penyampaian pada pelatihan ini adalah penjelasan tentang teori instalasi penerangan, syarat dan ketentuan pada instalasi penerangan dan selanjutnya diikuti dengan praktek pemasangan instalasi listrik pada bangunan.

Pelaksanaan kegiatan pelatihan instalasi penerangan ini dibimbing oleh 6 orang dosen yang bertugas sebagai instruktur dan dibantu oleh beberapa orang mahasiswa Teknik Elektro IT-PLN yang bertugas sebagai asisten instruktur. Untuk membuat pelatihan ini berdaya serap tinggi, pada saat praktek para peserta pelatihan instalasi penerangan ini dibagi dalam beberapa kelompok kecil dimana setiap kelompok terdiri atas 3 orang peserta didampingi oleh 2 orang asisten instruktur. Sehingga semua peserta dapat terlibat langsung mengerjakan praktek pemasangan instalasi penerangan pada modul yang sudah disiapkan. Hal ini terbukti efektif, karena pada akhir pertemuan peserta mengatakan bahwa pelatihan mudah dimengerti dan semua mendapatkan kesempatan untuk mempraktekkan pemasangan instalasi penerangan tersebut.

Beberapa foto-foto dokumentasi pada saat pelaksanaan pelatihan instalasi listrik penerangan dapat dilihat pada gambar berikut ini. 


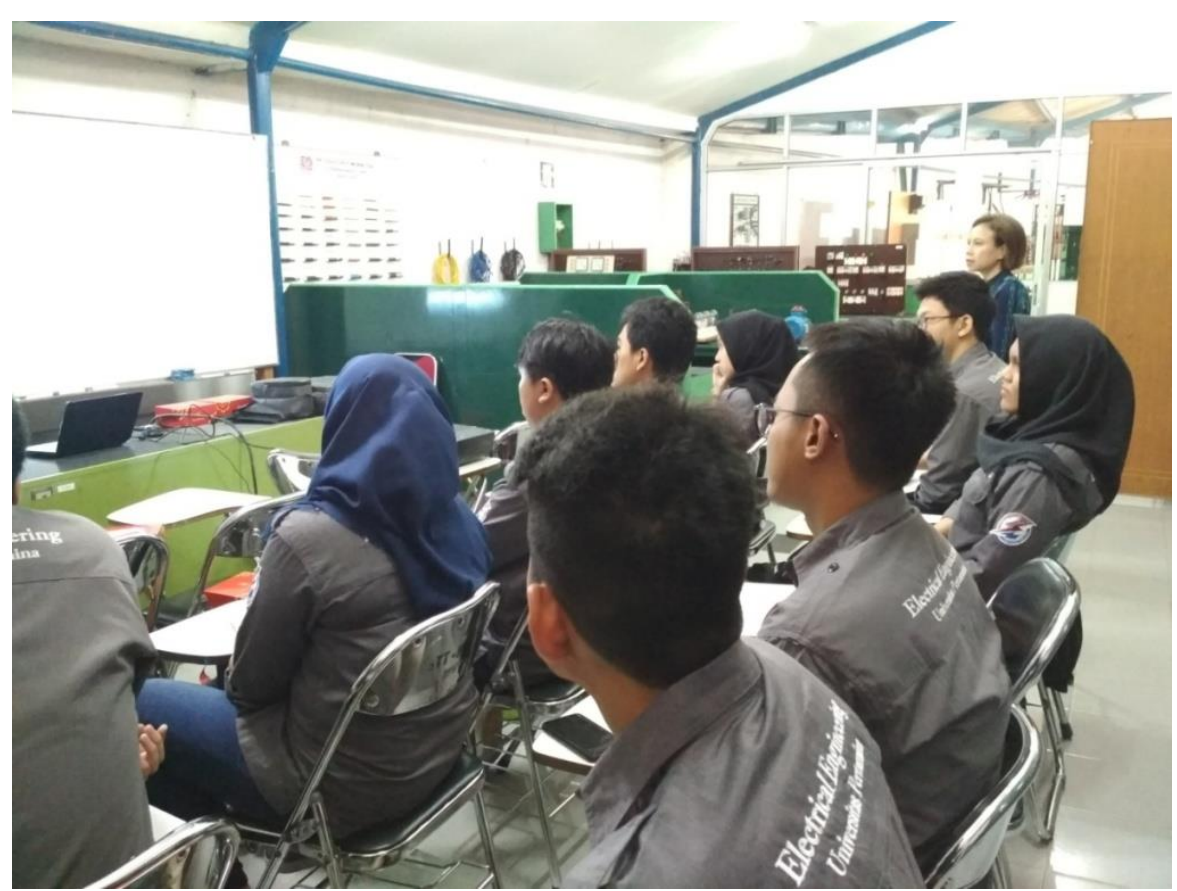

Gambar 1. Ketua Tim Pelaksana PKM Sedang Menjelaskan Materi Pelatihan Instalasi Penerangan

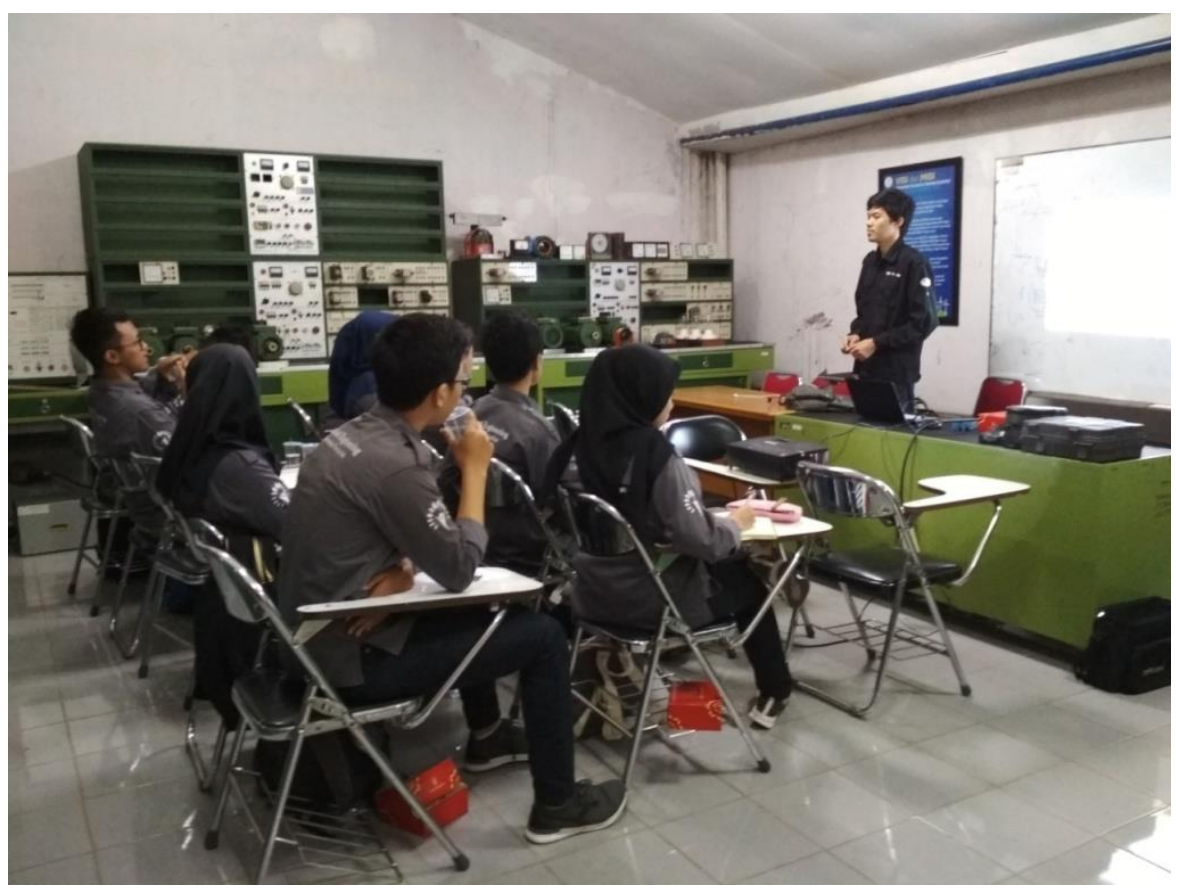

Gambar 2. Tim Pelaksana PKM Sedang Membuka Sesi Tanya Jawab 


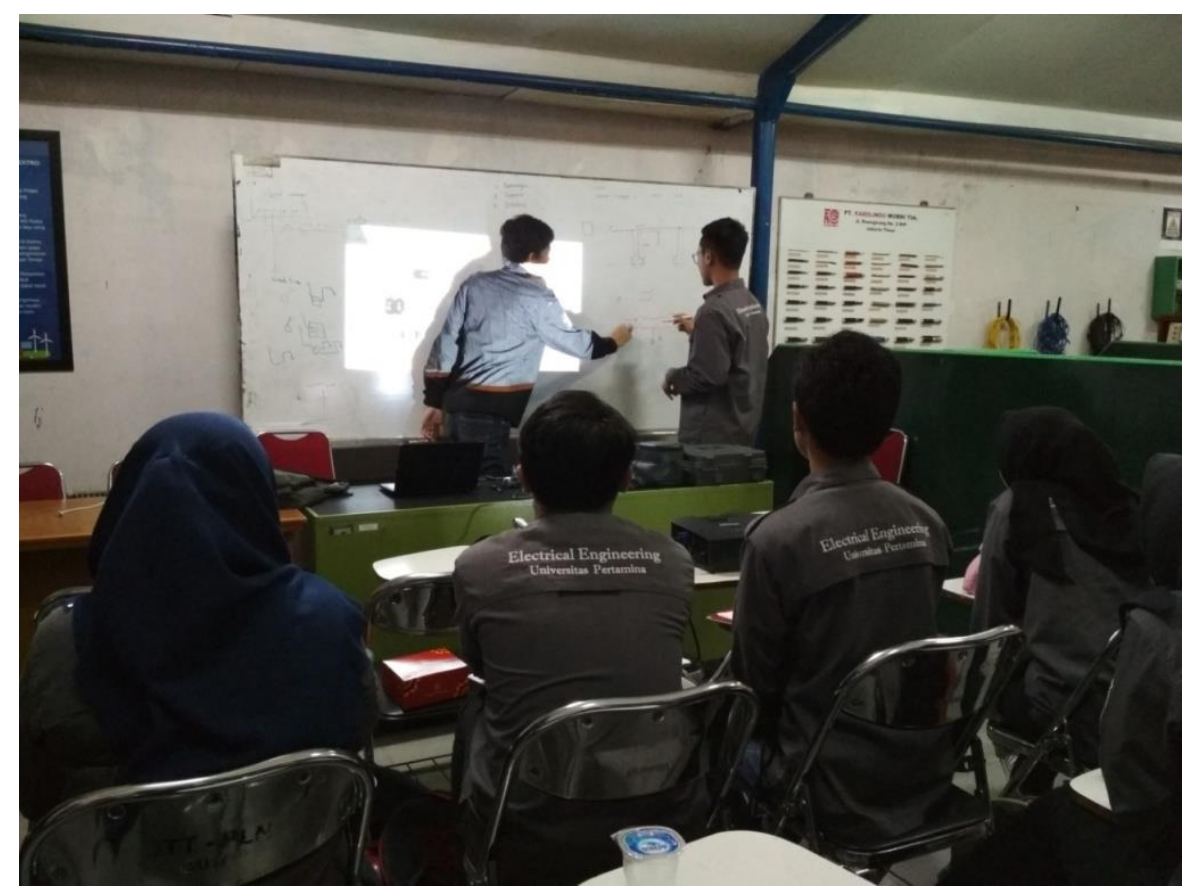

Gambar 3. Salah Satu Peserta Menggambarkan Wiring Diagram

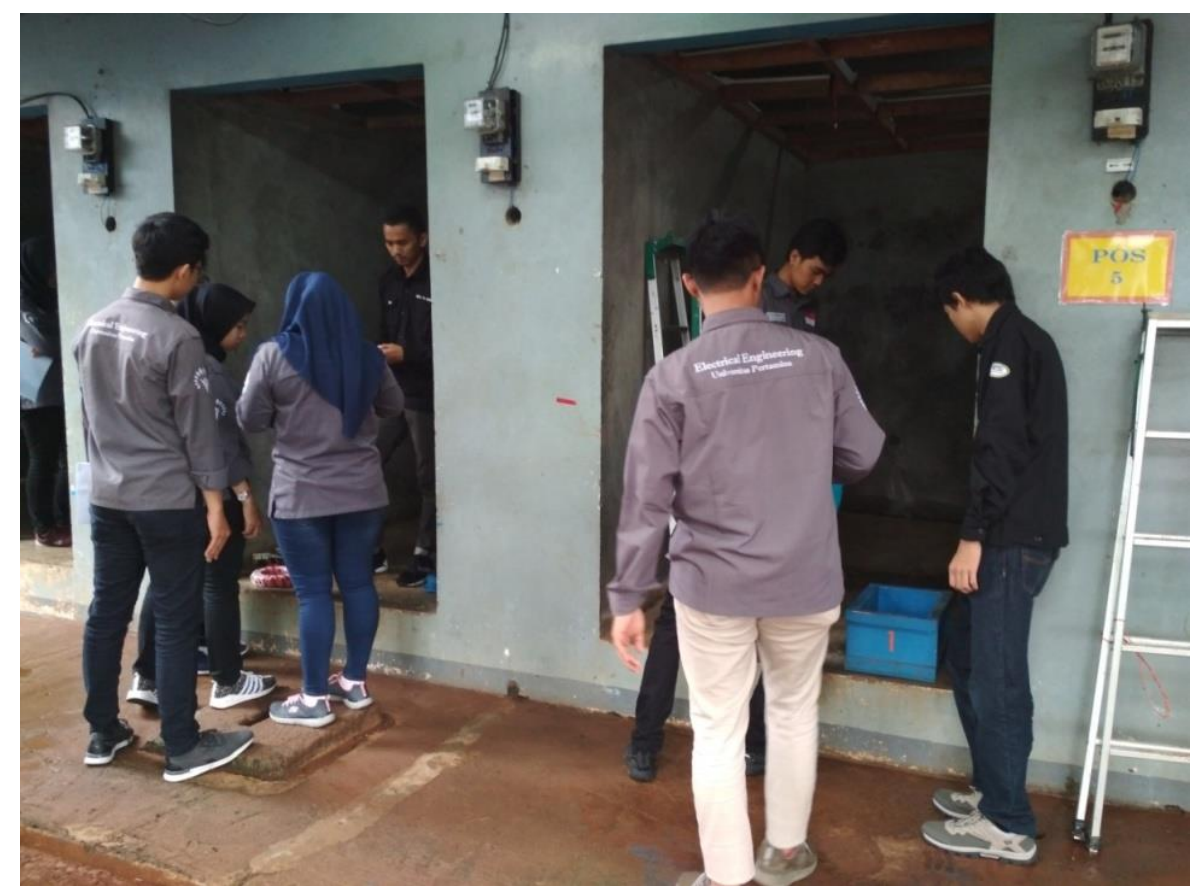

Gambar 4. Peserta Pelatihan Mendapatkan Bimbingan dan Penjelasan Dari Instruktur dan Asisten Instruktur 


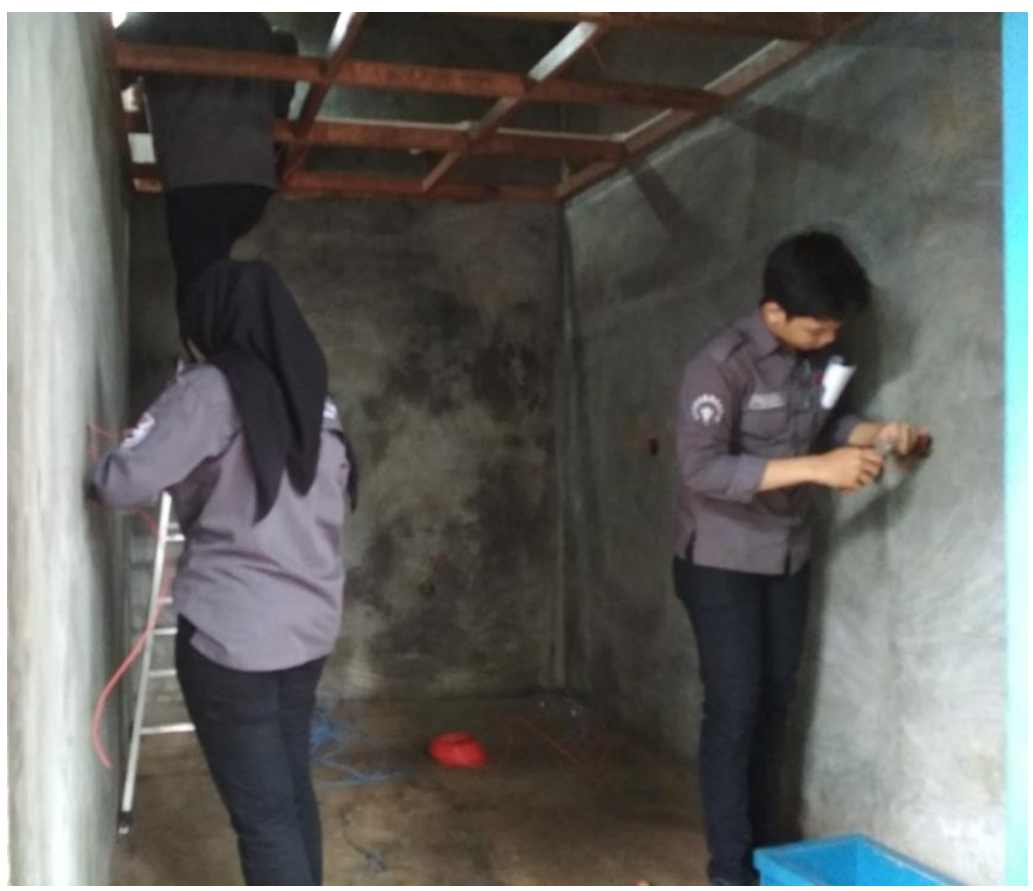

Gambar 5. Peserta Pelatihan Mempraktekkan Pemasangan Instalasi

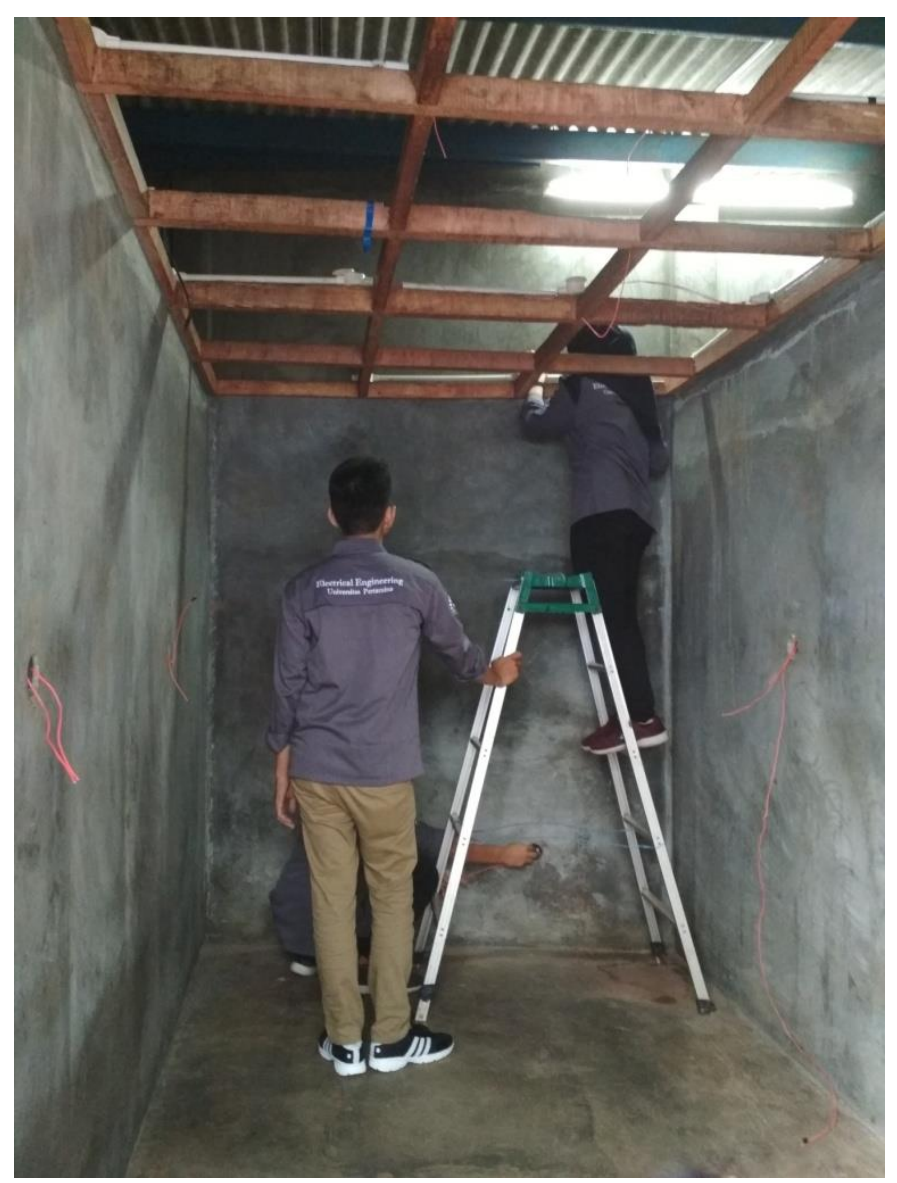

Gambar 6. Peserta Pelatihan Mempraktekkan Pemasangan Instalasi 


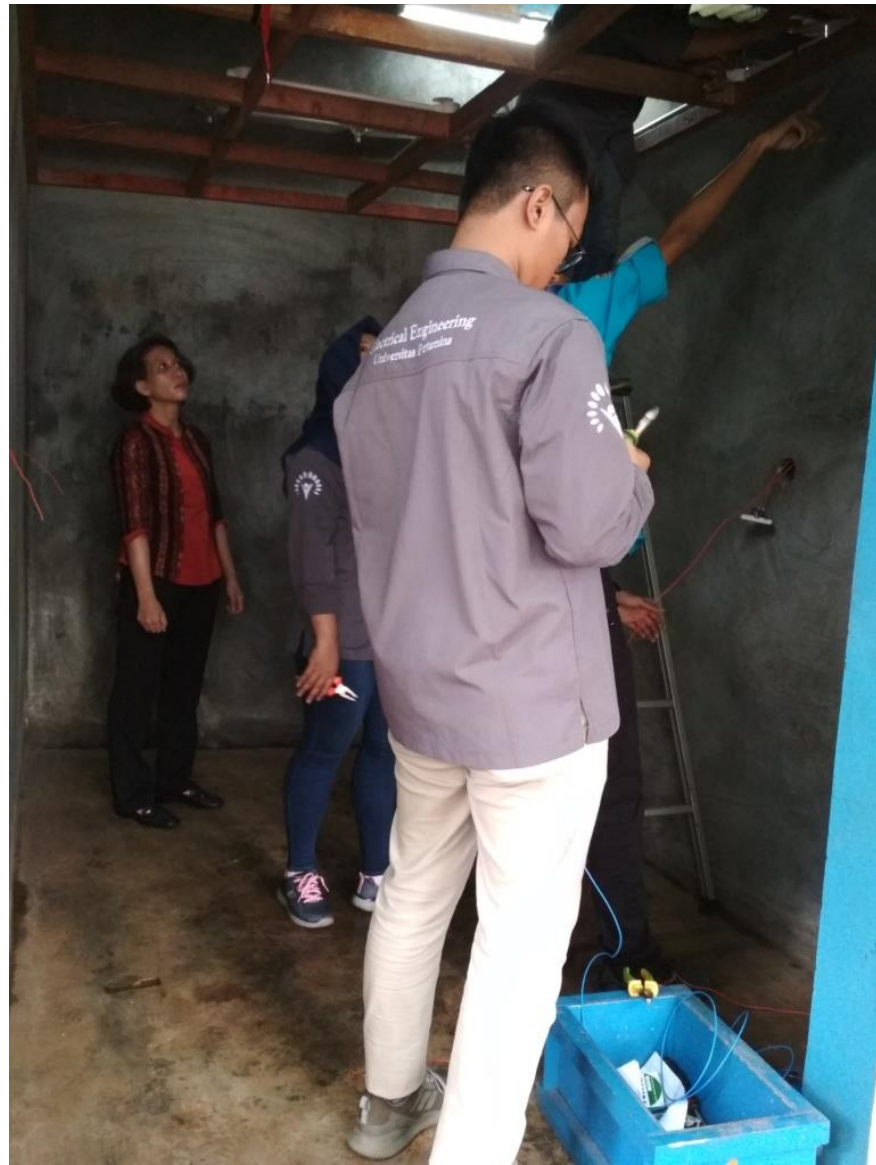

Gambar 7. Pemasangan Instalasi oleh Peserta Diawasi Langsung oleh Instruktur Pelatihan

Pengujian instalasi yang telah dipasang oleh peserta dilakukan dengan mengalirkan arus listrik dari kWhmeter. Sebelum dilakukan pengujian, hasil pemasangan instalasi penerangan oleh peserta, diperiksa terlebih dahulu apakah sudah sesuai dengan ketentuan dan gambar kerja yang diberikan. Apabila ada yang tidak sesuai peserta diberikan arahan kembali dan diminta untuk melakukan perbaikan. Setelah diperiksa dan dipastikan semuanya sudah benar baru dilakukan pengujian. Pada pengujian ini sistem instalasi listrik sesuai dengan yang direncanakan dan semua bekerja dengan baik.

Kegiatan PKM yang dilaksanakan di Universitas Pertamina ini berlangsung dengan baik dan mendapatkan antusiasme yang tinggi dari para peserta, ini terbukti para mahasiswa/mahasiswi dengan penuh semangat mengajukan pertanyaan sehingga tidak tercover bagi kami untuk memberikan waktu tambahan mengingat keterbatasan waktu, seperti yang terlihat pada gambar 2 dan gambar 3. Selain dari itu kegiatan ini mendapat sambutan yang baik dan dukungan penuh dari pihak Universitas Pertamina khususnya prodi Teknik Elektro. Bahkan Ketua Prodi Teknik Elektro-nya Bapak Dr.Eng. Wahyu Kunto Wibowo, S.T., M.Eng., meminta untuk mengikutkan semua mahasiswa Teknik Elektro Universitas Pertamina untuk bisa diberikan kesempatan yang langka ini. Tapi karena keterbatasan waktu dan dana maka kami para tim PKM dosen Teknik Elektro IT-PLN hanya bisa mengikutsertakan beberapa orang mahasiswa/mahasiswi saja dari berbagai angkatan.

Dengan memberikan pelatihan instalasi penerangan ini kepada para mahasiswa khususnya di sini mahasiswa / mahasiswi Teknik Elektro Universitas Pertamina, diharapkan mahasiswa / mahasiswi tersebut sudah mengetahui dan memahami tentang tata cara pemasangan instalasi listrik penerangan yang benar dan aman untuk sebuah bangunan yang sesuai dengan standar PUIL dan 
SPLN walaupun mereka bukan ahli yang memiliki kemampuan dasar pemasangan instalasi listrik. Tidak itu saja, melalui pelatihan instalasi penerangan ini, para mahasiswa/mahasiswi tersebut juga mendapatkan tambahan wawasan ilmu pengetahuan tentang bagaiamana cara penggunaan berbagai macam peralatan-peralatan yang dipakai dalam instalasi listrik penerangan beserta material-material berstandar SNI yang digunakan pada instalasi listrik penerangan.

\section{KESIMPULAN}

Setelah melaksanakan kegiatan PKM ini, dapat diambil beberapa kesimpulan antara lain:

1. Pelaksanaan kegiatan PKM dari tim dosen teknik elektro IT-PLN dalam bentuk memberikan pelatihan instalasi listrik penerangan kepada mahasiswa/mahasiswi Teknik Elektro Universitas Pertamina ini sangat perlu untuk dikembangkan agar kegiatan berikutnya menjadi lebih baik dan berguna di dalam peningkatan program kemitraan masyarakat yang menjadi bagian penting dalam mewujudkan "transferable skills" yang telah dipelajari dan dipahami

2. Antusiasme peserta mengikuti pelatihan sangat tinggi, baik pada saat pemaparan materi maupun pada saat pelaksanaan praktek pemasangan instalasi listrik. Hal ini dibuktikan dengan tingkat kehadiran dan keaktifan peserta pada saat pelaksanaan pelatihan

3. Materi pelatihan yang disampaikan oleh tim dosen teknik elektro IT-PLN dapat diserap dengan baik oleh para peserta sehingga pelaksanaan praktek pemasangan instalasi listrik dapat dilaksanakan sesuai dengan waktu yang disediakan

4. Melalui kegiatan PKM ini para mahasiswa/mahasiswi Teknik Elektro Universitas Pertamina memperoleh tambahan wawasan ilmu pengetahuan dan pemahaman mengenai tata cara pemasangan instalasi listrik penerangan yang baik dan benar beserta komponenkomponennya yang sesuai dengan SNI (Standar Nasional Indonesia), standar PUIL (Persyaratan Umum Instalasi Listrik) dan SPLN (Standar PLN), sehingga dapat diterapkan dalam kehidupan sehari-hari

5. Melalui pelaksanaan kegiatan PKM di Universitas Pertamina ini dapat menjadikan pihak Universitas Pertamina khususnya program studi Teknik Elektro-nya, ikut serta berperan aktif sebagai motivator untuk menumbuhkan kesadaran masyarakat mengenai pentingnya mengetahui dan memahami tata cara pemasangan instalasi listrik penerangan yang baik dan benar yang sesuai dengan standar PUIL dan SPLN. Sehingga tingkat keawaman masyarakat tentang tata cara pemasangan instalasi listrik penerangan yang baik dan benar itu dapat didegradasi.

\section{SARAN}

1. Kegiatan PKM mengenai pelatihan instalasi listrik penerangan yang diselenggarakan di Universitas Pertamina lebih tepatnya di Laboratorium Instrumentasi dan Pengukuran Listrik, masih perlu ditingkatkan dengan melibatkan sebanyak mungkin mahasiswa/mahasiswi yang ikut serta kegiatan pelatihan ini kedepannya, karena dengan semakin banyaknya mahasiswa/mahasiswi yang mengikuti kegiatan pelatihan tersebut maka akan semakin banyak pula mahasiswa/mahasiswi yang menyadari betapa pentingnya mengetahui dan memahami tata cara pemasangan instalasi listrik penerangan yang baik dan benar beserta komponen-komponennya yang sesuai dengan SNI, standar PUIL dan SPLN sehingga secara tidak langsung memberikan dampak positif terhadap masyarakat yang bertempat tinggal di sekitar lingkungan mereka 
2. Kedepannya pelaksanaan kegiatan pelatihan seperti ini tidak saja di sekolah-sekolah atau perguruan tinggi, tetapi seharusnya juga dapat dilaksanakan di lingkungan masyarakat yang bermukim di sekitar kampus IT-PLN.

\section{UCAPAN TERIMA KASIH}

Kami tim dosen Teknik Elektro IT-PLN sebagai pelaksana kegiatan PKM, menyampaikan ucapan terima kasih yang sebesar-besarnya kepada:

1. Pihak mitra yang dalam hal ini Universitas Pertamina khususnya Fakultas Teknologi Industri, Prodi Teknik Elektro yang telah menyediakan waktu dan tempat untuk kegiatan PKM ini

2. LPPM IT-PLN atas dukungan dana untuk kegiatan PKM dan segala macam bentuk bantuan yang diberikan kepada tim kami sehingga tim kami bisa melaksanakan kegiatan PKM ini dengan baik dan lancar.

\section{DAFTAR PUSTAKA}

[1] Asi, S., Buku Pegangan Kerja Menangani Teknik Tenaga Listrik Untuk Instalasi Listrik Rumah Tangga. Solo: CV. Aneka, 2000.

[2] BSN, Tata Cara Perancangan System Pencahayaan Buatan Pada Bangunan Gedung. Jakarta: Badan Standardisasi Nasional, 2001.

[3] Harten, P. Van dan Setiawan, E., Instalasi Listrik Arus Kuat 2. Jakarta: Trimitra Mandiri, 2002.

[4] Panitia PUIL, SNI 04-0225-2000, Persyaratan Umum Instalasi Listrik 2000. Jakarta: Direktorat Penyelidikan Masalah Bangunan.

[5] S, Heru dan Sulaeman, Materi Sertifikasi Pelatihan Keahlian Teknik Listrik. Jakarta: Asosiasi Profesionalis Elektrikal Indonesia (APEI), 2009.

[6] Seip, Gunter G., Electrical Installations Handbook, 3rd ed. Berlin, Siemens: John Wiley \& Sons, 2000.

[7] Setiawan, H. V., Instalasi Listrik Arus Kuat 1. Bandung: Bina Cipta, 1981.

[8] Sumardjati, Prih, dkk., Teknik Pemanfaatan Tenaga Listrik, Jilid 2. Jakarta: Departemen Pendidikan Nasional, 2008. 